\title{
Spatiotemporal trends in zooplankton biomass in the northern Humboldt current system off Peru from 1961-2012
}

\author{
Aronés Katia ${ }^{1,2,{ }^{*}}$, Grados Daniel ${ }^{1,3}$, Ayón Patricia ${ }^{1}$, Bertrand Arnaud ${ }^{3}$
}

1 Instituto del Mar del Perú (IMARPE), Apartado 22, Callao, Peru

2 Universidad Nacional Mayor de San Marcos (UNMSM), Apartado 12, Lima, Peru

${ }^{3}$ Institut de Recherche pour le Développement (IRD), MARBEC, Univ. Montpellier, CNRS, Ifremer, IRD, Sète, France

* Corresponding author : Katia Aronès, email address : karones72@gmail.com

\begin{abstract}
:
Anchovy (Engraulis ringens) is the most important exploited fish species in the Northern Humboldt Current System (NHCS) off Peru. This species, as well as most other pelagic resources, mainly forage on zooplankton. The NHCS is bottom-up controlled at a variety of scales. Therefore, fish biomass is driven by the abundance of their prey. In this context, we studied the spatiotemporal patterns of zooplankton biomass in the NHCS from 1961-2012. Data were collected with Hensen net all along the Peruvian coast. To transform zooplankton biovolume into biomass we used a regression that was calibrated from 145 zooplankton samples collected during four surveys and, for which, precise information was available on both biovolume and wet weight. The regression model was then applied on a time-series encompassing 158 cruises performed by the Peruvian Institute of the Sea (IMARPE) between 1961 and 2012. We observed a clear multidecadal pattern and two regime shifts, in 1973 and 1992 . Maximum biomass occurred between 1961 and 1973 (61.5 g m-2). The lowest biomass (17.8 g m-2) occurred between 1974 and 1992. Finally, the biomass increased after $1993(26.6 \mathrm{~g} \mathrm{~m}-2)$ but without reaching the levels observed before 1973. A seasonal pattern was observed with significantly more biomass in spring than in other seasons. Spatially, zooplankton biomass was higher offshore and in northern and southern Peru. Interestingly, the zooplankton sampling was performed using classic zooplankton net that are well fitted to mesozooplankton and are known to underestimate the macrozooplankton; however, the spatiotemporal patterns we observed are consistent with those of macrozooplankton, in particular euphausiids. This suggests that in the NHCS, when and where macrozooplankton dominates it also dominates the biomass obtained using classic zooplankton net samples. Finally, until now, in the NHCS only time-series on zooplankton biovolume were available. The biomass data we provide are more directly usable in trophic or end-to-end models.
\end{abstract}

Keywords : Secondary production, Mesozooplankton, Macrozooplankton, Regime-shift, Spatiotemporal distribution, Decadal trends 


\section{Introduction}

The Northern Humboldt Current System (NHCS) off Peru produces more fish per surface unit than any other marine ecosystem (Chavez et al., 2008). This system is characterised by an intense and shallow oxygen minimum zone (OMZ), which structures the ecosystem (Bertrand et al., 2011, 2014; Savatteci et al., 2019). The exceptional fish productivity observed since the early 20th century (Gutiérrez et al., 2009; Salvatteci et al., 2018,2019 ) is maintained by the upwelling of cold, nutrient-rich, low-oxygen, subsurface waters, concentrating life in a thin surface layer (Bertrand et al., 2014). This system is also sustained by weaker winds than other upwelling systems due to the low latitude of the region and hence greater Coriolis factor per given amount of turbulence (Bakun and Weeks, 2008). The main fishery resource is the Peruvian anchovy (Engraulis ringens), which account for $65 \%$ of worldwide anchovy production (Eurofish, 2012) and supports more than $90 \%$ of the GDP (Gross Domestic Product) of the Peruvian fishery sector (INEI, 2013). Anchovy is central not only because it constitutes the backbone of Peruvian fishery exports, but also by the role it plays in the food chain (e.g. Espinoza and Bertrand, 2008). For a long time, it was thought that anchovy was foraging directly on phytoplankton and that such short food web was responsible for the high productivity of the system (Ryther, 1969; Walsh, 1981). However, recent studies demonstrated that anchovy, as well as other pelagic species such as sardine (Sardinos sagax), jack mackerel (Trachurus murphyi) and mackerel (Scomber japonicus), are mostly zooplanktivorous (Espinoza and Bertrand, 2008, 2014; Espinoza et al., 2009; Alegre et al., 2015).

As in many other pelagic upwelling systems (e.g. Lindegren et al., 2016), the NHCS is bottom-up controlled at a variety of spatiotemporal scales ranging from the internal-wave scale (minutes - $100 \mathrm{~m}-1 \mathrm{~km}$ ) to millennial scales (Chavez et al., 2008; 
69 Gutiérrez et al., 2009; Ayón et al., 2011; Bertrand et al., 2011, 2014; Salvatteci et al., 2014,

70 2019). Consequently, even if fish foraging can lead to local zooplankton depletion (Ayón

71 et al., 2008b), changes in zooplankton biomass and composition directly impact higher

72 trophic levels (Ayón et al., 2011; Bertrand et al., 2011; Alegre et al., 2015). Some studies

73 already focused on the temporal trends in zooplankton biovolumes in the NHCS.

74 Specifically, Ayón et al. (2004) and Ayón and Swartzman (2008) analysed the

75 spatiotemporal trends in zooplankton biovolumes in the period 1964-2005 and identified

76 four time regimes: high zooplankton biovolume prior to 1974.5 , lower biovolume from

77 1974.5-1989.5, and average biovolume during 1989.5-1997.5 and 1997.5-2005. Each

78 regime was also associated with different spatial and seasonal patterns of zooplankton 79 biovolume.

80 To complete previous works, here we extend the series from Ayón et al. (2004) to

81 the period $1961-2012$ and express the zooplankton data in term of biomass instead of

82 biovolume to be more directly applicable in energetic studies and trophic models. Also, we

83 only use night data to better represent the total zooplankton biomass since most

84 zooplankton diel migrate and take refuge within the OMZ at day (e.g. Ballón et al., 2011).

85 With such data, we first examined decadal scales to identify possible regime shifts, but also

86 studied the seasonal patterns to compare with previous studies. Second, we described the

87 change in the spatial patterns of zooplankton distribution among decadal periods and

88 seasons. Finally, previous published zooplankton time-series and this study are based on

89 the use of classic zooplankton net (mesh size: $300 \mu \mathrm{m}$ ) that are fitted to observe

90 mesozooplankton but are known to underestimate the macrozooplankton (e.g., Fleminger

91 and Clutter, 1965). However, off Peru most pelagic fish take the bulk of their energy from

92 macrozooplankton (Espinoza and Bertrand, 2008; Espinoza et al., 2009, Alegre et al., 
93 2015). We therefore discuss if the image of the zooplankton community we provide is

94 consistent with macrozooplankton abundance.

95

96

97

98

99

100

101

102

103

104

105

106

107

108

109

110

111

112

113

114

115

116

117

\section{Materials and Methods}

Data were collected all along the diel cycle during 158 scientific surveys carried along the Peruvian coast by the Peruvian Institute of the Sea (IMARPE) between 1961 and 2012 (Fig. 1). Survey data covered the region up to $200 \mathrm{~km}$ from the coast but more than $95 \%$ of the data were collected within the first $100 \mathrm{~km}$ from the coastline. Zooplankton samples were collected by means of Hensen nets of $0.33 \mathrm{~m}^{2}$ mouth area with $300 \mu \mathrm{m}$ mesh, in vertical hauls from $50 \mathrm{~m}$ depth up to the surface. The zooplankton biovolume $(\mathrm{ml})$ was determined immediately after collection using the displacement method (Frolander, 1954, 1957; Kramer et al, 1972). Ichthyoplankton, that can damage other zooplankton individuals, and large coelenterates $(>2 \mathrm{~cm})$, that could bias the conversion from biovolume to biomass, were removed before determining the biovolume (Postel et al., 2000 Ayon et al., 2004). Samples were then fixed with $2 \%$ formaldehyde buffered with borax.

Here, to estimate the total zooplankton biovolume and biomass we only considered the 7538 plankton samples collected during the night. Indeed, diel vertical migration is a major feature in zooplankton (e.g. Haury et al., 1978). Off Peru, most abundant zooplanktonic species perform diel vertical migration (Ayón et al., 2008a). Ballón et al. (2011) estimated that $79 \%$ of macrozooplankton biomass vertically migrate and take refuge in the oxygen minimum zone during the day (Bertrand et al., 2008, 2014, Ballón et al., 2011). Finally, pelagic fish are adapted to this pattern since they can fit their foraging period and duration to prey availability in the surface layer (Espinoza and Bertrand, 2008). 
The biovolume (in $\mathrm{ml}$ ) of each zooplankton sample was converted into total

119 biovolume (in $\left.\mathrm{ml} \mathrm{m}^{-2}\right)$ using the mouth area of the net $\left(0.33 \mathrm{~m}^{2}\right)$. To convert this total

120 biovolume into wet weight biomass (in $\mathrm{g} \mathrm{m}^{-2}$ ) we used the following equation (Wiebe et

121 al., 1975; Wiebe, 1988):

$$
\log (D V)=a W W+b,
$$

123 where $D V$ is the displacement volume or biovolume (in $\mathrm{ml} \mathrm{m}^{-2}$ ) and $W W$ the wet weight (in

$124 \mathrm{~g} \mathrm{~m}^{-2}$ ), and $a$ (slope) and $b$ (intercept) are the coefficients of the regression. To estimate the 125 terms of the equation we used a set of 145 zooplankton samples from four surveys 126 performed in 1996 (46), 1998 (30), 2000 (34) and 2003 (35), for which we fully estimated

127 both the displacement volume and the wet weight. These data encompass a large range of 128 conditions (e.g. extreme El Niño in 1998 and strong La Niña in 2000) to ensure robustness.

129 This equation was further applied to the entire set of data to convert biovolume onto wet 130 weigh biomass.

131 The annual zooplankton biomass was estimated by averaging the different surveys

132 performed in each year. To seek for significant shifts in zooplankton biomass between 1331961 and 2012 we applied the Chow test (Chow, 1960).

134 To describe spatial variation among periods and seasons we interpolated the data 135 with the "kriging" method using Surfer v.15.0. For spatial analysis, the Peruvian coast has 136 also been divided into three latitudinal areas: A $\left(03^{\circ} 30^{\prime} \mathrm{S}-05^{\circ} 59^{\prime} \mathrm{S}\right), \mathrm{B}\left(06^{\circ} 00^{\prime} \mathrm{S}-13^{\circ} 59^{\prime} \mathrm{S}\right)$ 137 and $\mathrm{C}\left(14^{\circ} 00^{`} \mathrm{~S}-18^{\circ} 20^{`} \mathrm{~S}\right)$ according to previous works on the spatial patterns of 138 oceanographic conditions (e.g. Carrasco and Lozano, 1989), oxygen concentration (e.g. 139 Bertrand et al., 2010), primary productivity (e.g. Echevin et al., 2008), zooplankton 140 distribution (e.g. Ballón et al., 2011) and anchovy distribution (e.g. Simmonds et al., 2009). The biomass were compared by period (resulting from the Chow test), by area 
143 ecological domain (Inshore, Offshore). Differences between factors were tested using an

144 ANOVA. Before performing the analyses, we normalised the data by applying a Box-Cox 145 transformation (Box and Cox, 1964).

\section{Results}

The $a$ (slope) and $b$ (intercept) terms of the biovolume-wet weight biomass equation were estimated to be 0.9896 and 0.016 , respectively $\left(r^{2}=0.986\right)(\mathrm{Fig} .2)$.

\subsection{Spatiotemporal patterns at the decadal scale}

Mean annual zooplankton biomasses varied between 3.7 g.m $\mathrm{m}^{-2}$ and $100.6 \mathrm{~g} \cdot \mathrm{m}^{-2}$. The lowest biomass was recorded in 1976 and the highest in 1967 (Fig. 3). Highest biomasses were found during the first years of our time series, these values progressively dropped in

158 the early 1970s. Then, the biomass increased from the 1990s but without reaching the high

159 values of the 1960s. Indeed, the Chow test depicted two significant regime shifts, in 1973

160 and 1992. Differences between periods were highly significant (ANOVA p<0.0001).

161 Maximum biomass occurred between 1961 and 1973 (mean 61.5 g.m ${ }^{-2}$ ). The lowest

162 biomass $\left(17.8\right.$ g.m $\left.\mathrm{m}^{-2}\right)$ occurred during the second period between 1974 and 1992. Finally,

163 the biomass was average $\left(26.6 \mathrm{~g} . \mathrm{m}^{-2}\right)$ during the third period that began in 1993 (Fig. 3,

164 Table 1).

165 Spatially the zooplankton biomass presented different patterns according to the period (Fig.

166 4, Table 1). During the first period (1961-1973), the biomass was significantly higher 
167 offshore than inshore (ANOVA, $\mathrm{p}<0.0001$ ). This pattern was not observed in the

168 following periods that had similar biomass offshore and inshore.

169 The biomasses were significantly different between Areas (ANOVA, $\mathrm{p}<0.0001$ ), 170 being significantly higher in the north (area A) in all periods (Fig. 4, Table 1). The lower

171 biomass was observed in centre-north (area B), except during the last period when biomass

172 was similar between areas B and C (southern Peru).

173

\subsection{Spatiotemporal patterns at the seasonal scale}

175

Zooplankton biomass presented a significant seasonal (ANOVA, $\mathrm{p}<0.0001$ ) pattern

177 (Fig. 5) with a maximum in spring (48.3 g.m $\left.{ }^{-2}\right)$, a minimum in autumn $\left(25.5\right.$ g.m $\left.\mathrm{m}^{-2}\right)$ while 178 summer and winter biomass were alike with 30.4 g.m $\mathrm{m}^{-2}$ and 30.6 g.m $\mathrm{m}^{-2}$, respectively (Table

179 1). The seasonal differences we strongest during the first period than then after.

180 In spring, when the highest biomass occur, the bulk of zooplankton was distributed

181 offshore (Table 2). This difference was much lower in autumn when the estimated biomass

182 was the lower (Table 2). The biomasses were higher in Area A in summer and autumn,

183 while in spring and winter they were similarly distributed among the three areas (Fig. 6,

184 Table 2).

\section{4. Discussion}

The two significant regime shifts observed in 1973 and 1992 are slightly different

189 from those proposed by Ayón and Swartzman (2008) (1974.5, 1989.5 and 1997.5). These

190 differences can be related to at least two aspects. First, contrarily to this study, they used

191 both day and night data, which can confound the results since most zooplankton undergo 
192 diel vertical migration (Ballón et al., 2011). Second, our discrimination is based on

193 biomass only when Ayón and Swartzman (2008) considered a variety of spatiotemporal 194 factors including the diel cycle.

195 However, the shifts we depicted are consistent with the semi-qualitative analysis

196 performed by Ayón et al. (2011) that studied the relative dominance of different size-

197 classes of over 15,000 zooplankton data between 1963 and 2005. They showed that the

198 temporal patterns of large zooplankton in general and euphausiids in particular, presented

199 different periods, similar to those we observed considering the total biomass. They

200 observed higher proportion of macrozooplankton before the mid-1970s and after the mid-

201 1990s. Macrozooplankton avoid nets, in particular small nets, because of both visual and

202 mechanical disturbances (Fleminger and Clutter, 1965; Debby et al., 2004; Lawson et al.

203 2008). The spatiotemporal patterns we observed are globally consistent with those of 204 macrozooplankton, in particular euphausiids (Ayón et al., 2011; Ballón et al., 2011).

205 Therefore, in the NHCS, when and where macrozooplankton dominates, it also dominates

206 the biomass obtained using classic zooplankton net samples. This suggests that large

207 organisms such as euphausiids and large copepods likely dominate the zooplankton

208 biomass in the NHCS and govern our biomass time-series, but are underestimated by our 209 sampling method. Ayón et al. (2011) showed that anchovy abundance was significantly

210 correlated to macrozooplankton dominance, which is also partially represented in our time

211 series. These results are also consistent with the fact that small pelagic fish forage on larger

212 zooplankters in the NHCS when compared with other eastern boundary current systems

213 (Espinoza et al., 2009).

214 Interestingly, anchovy, which forage on zooplankton, showed a significant shift in 2151992 with an increase in abundance after this date that stabilised in the late 1990s 216 (Gutiérrez et al., 2007). Alegre et al. (2015) also observed a shift in the diet composition of 
217 the jack mackerel in the early 1990s. Similarly, a copepod biomass (1988-2008) from

218 northern Chile (Escribano et al., 2012) also showed a similar shift in 1992. Escribano et al.

219 (2012) observed, however, a strong decline in copepod biomass during and after the 1997-

22098 El Niño that we do not observe in our data. Finally, the regime shifts we observed are

221 consistent with Bertrand et al. (2011) who showed that anchovy flourish under relatively

222 low oxygen conditions that are also characterised by high macrozooplankton biomass. We

223 conclude that a major re-structuring of the system occurred, therefore, in the early 1970s 224 and 1990s.

While we observed significant decadal shifts, extreme El Niño (e.g. 1982-83 and 1997-98) or strong La Niña (e.g. 1975 or 2000) events did not appear to trigger these regime shifts. Similar observations were observed in a variety of ecosystem components with no evident effect (e.g. anchovy diet, Espinoza and Bertrand, 2008, or mackerel and jack mackerel diet, Alegre et al., 2015). As stated by Alegre et al. (2015), in this system, macrozooplankton abundance seem highly resilient to El Niño events (see also Brinton, 1967 and Arones et al., 2009).

Ballón et al. (2011) reviewed the zooplankton biomass estimations of meso- and macrozooplankton in two upwelling systems, Antarctic and eastern Canada. Estimates in upwelling systems ranged between 3.5 and $113.8 \mathrm{~g} \mathrm{~m}^{-2}$ depending on the period or the system. For Peru, our estimates are higher than those from Ayón et al. (2004) converted into biomass by Ballón et al. (2011). This is likely due to the fact that we considered night samples only to provide a more robust estimation of the total biomass. Indeed, Ballón et al. (2011) estimated that $\sim 79 \%$ of the macrozooplankton biomass perform diel migration and distribute in the deep layer during the day, out of range from the net sampling. Still, our estimations are far below the acoustic macrozooplankton biomass estimations from Ballón et al. (2011) ( 100 $\mathrm{g} \mathrm{m}^{-2}$ during the mid-2000). Therefore, the total zooplankton biomass is 
242 probably higher than our estimates but lower than the sum of our results and those of

243 Ballón et al. (2011).

244 Our biomass results are comparable with the estimates in southern HCS off Chile

245 (Escribano et al., 2009) and with measurements in the California, Canaria and Benguela

246 Current systems for the period of the 1960s (Cushing, 1971). They are, however, much

247 higher than recent estimates in the California Current system (e.g. Lavaniegos and Ohman, 248 2007).

249 Spatially we observed significantly more zooplankton biomass offshore than 250 inshore during the first period (1961-1973). However, this trend was not observed in the 251 two most recent periods. This result is puzzling since macrozooplankton, biomass is much 252 higher off the shelf break (Ballón et al., 2011). Indeed euphausiids are mainly distributed 253 off the shelf where they use the oxygen minimum zone as a refuge area (Ballón et al., 254 2011). On the other hand, the consistent higher biomass observed in northern Peru (zone 255 A) and lower biomass in central-north Peru (area B) is consistent with the results of Ballón 256 et al. (2011). In all areas, we observed a decline in biomass during 1973-1992 but this 257 reduction was stronger in the northern and southern areas.

258 Seasonally, we observed the highest zooplankton biomass in spring, rather low 259 values in summer and winter and the lowest biomass in autumn, which is consistent with 260 Ayón et al. (2008a). In northern Peru, Arones et al. (2009) observed higher zooplankton 261 abundance in summer and autumn than spring. However, this study focused on a specific 262 transect during a shorter period (1994-2004, with the exclusion of the El Niño-La Niña 263 period ranging from Feb. 1997 to Nov. 1999). Overall our results are consistent with the 264 fact that spring-summer are the periods of highest primary productivity in the NHCS 265 (Echevin et al., 2008; Passuni et al., 2016, 2018) and when the oceanic front is closer to the coast (Swartzman et al., 2008), concentrating overall productivity. 
In conclusion, this study provides the first estimation of zooplankton biomass in the

268 NHCS off Peru over a multi-decadal period. We depicted two significant regime shifts in

2691973 and 1992. The highest biomass occurred before 1973, the lowest during 1973-1992

270 and average values then after. These shifts are consistent with other studies on zooplankton

271 or forage fish (e.g. Gutiérrez et al., 2007; Ayón et al., 2011). Spatially, zooplankton

272 biomass was higher offshore and in northern and southern Peru. Zooplankton biomass was

273 also higher during spring than other seasons. Finally, until now, only time-series on 274 zooplankton biovolume were available for the NHCS (Carrasco and Lozano, 1989; Ayón

275 et al., 2004; Ayón and Swartzman, 2008). The biomass data we provide here are more

276 directly usable in trophic and end-to-end models.

277

278 Acknowledgements

279

280

This publication was carried out with the support of the IRD - JEAI EMACEP

281 (Quantitative Marine Ecology of the Peruvian Upwelling Ecosystem) and is a contribution 282 to the IRD-IMARPE international joint laboratory DISCOH. 
References

286

287 Alegre, A., Bertrand, A., Espino, M., Espinoza, P., Dioses, T., Niquen, P., Navarro, I., 288 Simier, M., Ménard, F., 2015. Diet diversity of jack and chub mackerels and ecosystem 289 changes in the northern Humboldt Current system: a long-term study. Prog. Oceanogr. $290 \quad 137,299-313$

291 Aronés, K., Ayón, P., Hirche, H.J., Schwamborn, R. 2009. Hydrographic structure and 292 zooplankton abundance and diversity off Paita, northern Peru (1994 to 2004)—ENSO 293 effects, trends and changes. J. Mar. Syst., 78, 582-598.

294 Ayón P, Purca S, Guevara-Carrasco R., 2004. Zooplankton volume trends off Peru 295 between 1964 and 2001. ICES J. Mar. Sci. Symp. 61:478-484.

296 Ayón, P., G. Swartzman., 2008. Changes in the long-term distribution of zooplankton in 297 the Humboldt Current Ecosystem off Peru, 1961-2005, and its relationship to regime 298 shifts and environmental factors. Fish. Oceanogr. 17:6, 421-431.

299 Ayón, P., Criales-Hernandez, M.I., Schwamborn, R., Hirche, H.J., 2008a. Zooplankton $300 \quad$ research off Peru: a review. Prog. Oceanogr. 79, 238-255.

301 Ayón P., Swartzman G., Bertrand A., Gutiérrez M., Bertrand S. 2008b. Zooplankton and 302 forage fish species off Peru: large-scale bottom-up forcing and local-scale depletion. 303 Prog. Oceanogr., 79: 208-214. DOI: 10.1016/j.pocean.2008.10.023

304 Ayón, P., Swartzman, G., Espinoza, P., Bertrand, A., 2011. Long-term changes in 305 zooplankton size distribution in the Peruvian Humboldt Current System: conditions 306 favouring sardine or anchovy. Mar. Ecol. Prog. Ser. 422, 211-222.

307 Ballón M, Bertrand A, Lebourges-Dhaussy A, Gutiérrez M, Ayón P, Grados D, Gerlotto 308 F., 2011. Is there enough zooplankton to feed forage fish population off Peru? An 
acoustic (positive) answer. Prog. Oceanogr. 91, 360-381.

$310 \quad$ doi:10.1016/j.pocean.2011.03.001.

311 Bakun, A., \& Weeks, S. J. 2008. The marine ecosystem off Peru: What are the secrets of

312 its fishery productivity and what might its future hold?. Prog. Oceanogr. 79(2-4), 290313299.

314 Bertrand, A., Ballón, M., Chaigneau, A. 2010. Acoustic observation of living organisms 315 reveals the oxygen minimum zone. PLoS ONE 5, e10330.

316 Bertrand, A., Gerlotto, F., Bertrand, S., Gutiérrez, M., Alza, L., Chipollini, A., Díaz, E.,

317 Espinoza, P., Ledesma, J., Quesquén, R., Peraltilla, S., Chavez, F., 2008. Schooling 318 behaviour and environmental forcing in relation to anchoveta distribution: an analysis 319 across multiple spatial scales. Prog. Oceanogr. 79(2-4), 264-277.

320 Bertrand, A., Chaigneau, A., Peraltilla, S., Ledesma, J., Graco, M., Monetti, F., Chavez, F., 2011. Oxygen, a fundamental property regulating pelagic ecosystem structure in the coastal southeastern tropical Pacific. PLoS ONE 6, e29558.

Bertrand, A., Grados, D., Colas, F., Bertrand, S., Capet, X., Chaigneau, A., Vargas, G., Mousseigne, A., Fablet, R., 2014. Broad impacts of fine-scale dynamics on seascape structure from zooplankton to seabirds. Nat. Com. 5, 5239.

Box, G.E.P., Cox, D. R. 1964. An analysis of transformations. J. R. Stat. Soc. Series B Stat. Methodol., 26, 211-234.

Brinton, E. 1967. Vertical migration and avoidance capability of euphausiids in the California Current. Lim. Oceanogr. 12(3), 451-483.

330 Carrasco, S., Lozano, O., 1989. Seasonal and long-term variations of zooplankton 331 volumes in the Peruvian Sea 1964 - 1987. In The Peruvian Upwelling Ecosystem: 332 Dynamics and Interactions, pp. 82-85. Ed. by D. Pauly, D. Muck, J. Mendo, and I. 333 Tsukayama. ICLARM. 438pp. 
334 Chavez, F.P., Bertrand, A., Guevara-Carrasco, R., Soler, P., Csirke, J., 2008. The northern

335 Humboldt Current System: brief history, present status and a view towards the future.

336 Prog. Oceanogr. 79, 95-105. DOI: 10.1016/j.pocean.2008.10.012.

337 Chow, G.C., 1960. Tests of equality between sets of coefficients in two linear 338 regressions. Econometrica: J. Econ. Soc. 591-605.

339 Cushing, D.H., 1971. Upwelling and the production of fish. Adv. Mar. Biol. 9, 255-300.

340 Debby, L., Jackson, G.A., Angel, M.V., Lampitt, R.S., Burd, A.B., 2004. Effect of 341 netavoidance on estimates of diel vertical migration. Lim. Oceanogr. 46, 2297-2303.

342 Echevin, V., Aumont, O., Ledesma, J., Flores, G., 2008. The seasonal cycle of surface

343 chlorophyll in the Peruvian upwelling system: A modelling study. Prog.

$344 \quad$ Oceanogr. 79(2-4), 167-176.

345 Escribano, R., Hidalgo, P., Krautz, C., 2009. Zooplankton associated with the oxygen

346 minimum zone system in the northern upwelling region of Chile during March 2000.

347 Deep-Sea Res. Part II 56, 1083-1094.

348 Escribano, R., Hidalgo, P., Fuentes, M., Donoso, K., 2012. Zooplankton time series in the 349 coastal zone off Chile: Variation in upwelling and responses of the copepod $350 \quad$ community. Prog. Oceanogr. 97, 174-186.

351 Espinoza, P., Bertrand, A., 2008. Revisiting Peruvian anchovy (Engraulis ringens) 352 trophodynamics provides a new vision of the Humboldt Current system. Prog. 353 Oceanogr. 79, 215-227.

354 Espinoza, P., Bertrand, A., 2014. Ontogenetic and spatiotemporal variability in anchoveta 355 Engraulis ringens diet off Peru. J. fish biol. 84(2), 422-435.

356 Espinoza, P., Bertrand, A., Van der Lingen, C.D., Garrido, S., Rojas de Mendiola, B., 357 2009. Diet of sardine (Sardinops sagax) in the northern Humboldt Current system and 
comparison with the diets of clupeoids in this and other eastern boundary upwelling systems. Prog. Oceanogr. 83, 242-250.

360 Eurofish International Organisation., 2012. Overview of the world's anchovy sector and

361 trade possibilities for Georgian anchovy products Organisation, available at:

362 http://www.fao.org/fileadmin/user_upload/Europe/documents/Publications/

363 Anchovies_report_2.03.2012.pdf.

364 Fleminger, A., Clutter, R.I., 1965. Avoidance of towed nets by zooplankton. Lim.

365 Oceanogr. 10, 96-104.

366 Frolander H., 1954. Plankton volume displacement indicator. University of Washington

367 Deparment of Oceanography. Seattle 5, WAshington. Tech.1 Report No 25.

368 Frolander, H. F. 1957. A plankton volume indicator. ICES J. Mar. Sci. 22(3), 278-283.

369 Gutierrez, M., Swartzman, G., Bertrand, A., Bertrand, S., 2007. Anchovy (Engraulis

370 ringens) and sardine (Sardinops sagax) spatial dynamics and aggregation patterns in the

371 Humboldt Current ecosystem, Peru, from 1983-2003. Fish. Oceanogr. 16(2), 155-168.

372 Gutiérrez, D., Sifeddine, A., Field, D., Ortlieb, L., Vargas, G., Chavez, F. Velazco, 373 F.,Ferreira, V., Tapia, P., Salvatteci, R., Boucher, H., Morales, M. C., Valdes, J., Reyss, 374 J.-L., Campusano, A., Boussafir, M. Mandeng-Yogo, M., Garcia, M. and Baumgartner, 375 T., 2009. Rapid reorganization in ocean biogeochemistry off Peru towards the end of 376 the Little Ice Age. Biogeoscince 6, 835-848.

377 Haury, L. R., McGowan, J. A., \& Wiebe, P. H. 1978. Patterns and processes in the time378 space scales of plankton distributions. In Spatial pattern in plankton communities (pp. 379 277-327). Springer, Boston, MA.

380 INEI., 2013. Compendio Estadístico del Perú. Instituto Nacional de Estadística e Informatica. www.inei.gob.pe. 
382 Kramer, D., Kalin, M.J., Stevens, E.G., Thrailkill, J.R., and Zweifel, J.R., 1972. Collecting

383 and processing data on fish eggs and larvae in the California Current region. NOAA 384 Tech. Rep. NMFS Circ-370: 1-38.

385 Lavaniegos, B.E., Ohman, M.D., 2007. Coherence of long-term variations of zooplankton 386 in two sectors of the California Current system. Prog. Oceanogr. 75, 42-69.

387 Lawson, G. L., Wiebe, P. H., Ashjian, C. J., \& Stanton, T. K., 2008. Euphausiid 388 distribution along the Western Antarctic Peninsula-Part B: distribution of euphausiid aggregations and biomass, and associations with environmental features. Deep-Sea Res.

391 Lindegren, M., Checkley, D.M., Ohman, M.D., Koslow, J.A., Goericke R. 2016.

392 Resilience and stability of a pelagic marine ecosystem Proc. R. Soc. B Biol. Sci., 283, p. 39320151931.

394 Passuni, G., Barbraud, C., Chaigneau, A., Demarcq, H., Ledesma, J., Bertrand, A., 395 Castillo, R., Perea, A., Mori, J., Viblanc, V.A., Torres-Maita, J., Bertrand, S., 2016. 396 Seasonality in marine ecosystems: Peruvian seabirds, anchovy and oceanographic conditions. Ecology 97(1), 182-193. https://doi.org/10.1890/14-1134.1.

Passuni, G., Barbraud, C., Chaigneau, A., Bertrand, A., Oliveros-Ramos, R., Ledesma, J., 399 Castillo, R., Bouchon, M., Bertrand, S., 2018. Long-term changes in the breeding 400 seasonality of Peruvian seabirds and regime shifts in the Northern Humboldt Current 401 System. Mar. Ecol. Progr. Ser. 597, 231-242.

Postel, L., Fock, H., \& Hagen, W. 2000. Biomass and abundance. In ICES zooplankton methodology manual (pp. 83-192). Academic Press.

404 Ryther J. H., 1969. Photosynthesis and fish production in the sea. Sci.166: 72-76.

405 Salvatteci, R., Gutiérrez, D., Field, D., Sifeddine, A., Ortlieb, L., Bouloubassi, I., 406 Boussafir, M., Boucher, H., Cetin, F., 2014. The response of the Peruvian Upwelling 
407 Ecosystem to centennial-scale global change during the last two millennia. Clim $408 \quad$ Past. 10(2), 715-731.

409 Salvatteci, R., Gutierrez, D., Field, D., Sifeddine, A., Ortlieb, L., Caquineau, S., 410 Baumgartner, T., Ferreira, V., Bertrand, A. 2019. Fish debris in sediments from the last $41125 \mathrm{kyr}$ in the Humboldt Current reveal the role of productivity and oxygen on small 412 pelagic fishes. Prog. Oceanogr., In Press. DOI: 10.1016/j.pocean.2019.05.006

413 Simmonds, J., Gutiérrez, M., Chipolini, A., Gerlotto, F., Woillez, M., Bertrand, A. 2009. 414 Acoustic surveys for Peruvian anchoveta: Optimisation of survey design. ICES J. Mar. $415 \quad$ Sci., 66, 1341-1348.

416 Swartzman, G., Bertrand, A., Gutiérrez, M., Bertrand, S., Vasquez, L. 2008. The 417 relationship of anchovy and sardine to water masses in the Peruvian Humboldt Current 418 System from 1983-2005. Prog. Oceanogr., 79, 228-237.

419 Walsh, J. J., 1981. A carbon budget for overfishing off Peru. Nature, 290(5804), 300.

420 Wiebe, P.H., 1988. Functional regression equations for zooplankton displacement volume, 421 wet weight, dry weight and carbon: a correction. Fish. Bull. 86,

422 Wiebe, P.H., Boyd, S.H., Cox, J.L., 1975. Relationships between zooplankton 423 displacement volume, wet weight, dry weight, and carbon. Fish. Bull. US 73, 777-786. 


\section{TABLES}

2

3 Table 1. Zooplankton mean biomass (in $\mathrm{g} \mathrm{m}^{-2}$ ) by season and by ecological domain for the

4 complete time-series and by period.

\begin{tabular}{ccccccccccc}
\hline Period & Total & Summer & Autumn & Winter & Spring & Inshore & Offshore & Area A & Area B & Area C \\
& & & & & & & & & & \\
A & & & & & & & \\
\hline $1961-1973$ & 61.5 & 62.4 & 35.2 & 42.0 & 92.1 & 42.3 & 70.4 & 93.7 & 49.7 & 76.6 \\
$1974-1992$ & 17.8 & 17.9 & 19.0 & 15.2 & 19.7 & 17.1 & 18.2 & 23.1 & 16.6 & 17.9 \\
$1993-2012$ & 26.6 & 25.8 & 23.7 & 25.7 & 30.2 & 19.8 & 30.7 & 35.7 & 25.6 & 24.0 \\
All & 34.6 & 30.4 & 25.5 & 30.6 & 48.3 & 24.8 & 40.0 & 47.0 & 31.0 & 36.1
\end{tabular}

5

6 Table 2. Zooplankton mean seasonal biomass (in $\mathrm{g} \mathrm{m}^{-2}$ ) by area and ecological domain.

\begin{tabular}{|c|c|c|c|c|c|c|c|c|}
\hline \multirow[t]{2}{*}{ Area } & \multicolumn{2}{|c|}{ Summer } & \multicolumn{2}{|c|}{ Autumn } & \multicolumn{2}{|c|}{ Winter } & \multicolumn{2}{|c|}{ Spring } \\
\hline & Inshore & Offshore & Inshore & Offshore & Inshore & Offshore & Inshore & Offshore \\
\hline $\mathrm{A}$ & 26.7 & 57.2 & 21.8 & 36.2 & 22.7 & 44.5 & 50.6 & 74.0 \\
\hline B & 20.0 & 36.6 & 21.2 & 26.7 & 27.6 & 29.2 & 30.0 & 48.3 \\
\hline $\mathrm{C}$ & 13.5 & 25.7 & 17.5 & 26.0 & 25.8 & 32.3 & 41.1 & 61.4 \\
\hline All & 20.2 & 36.7 & 20.9 & 28.0 & 27.2 & 32.3 & 32.2 & 56.6 \\
\hline
\end{tabular}

7 
8 Figures

9

10

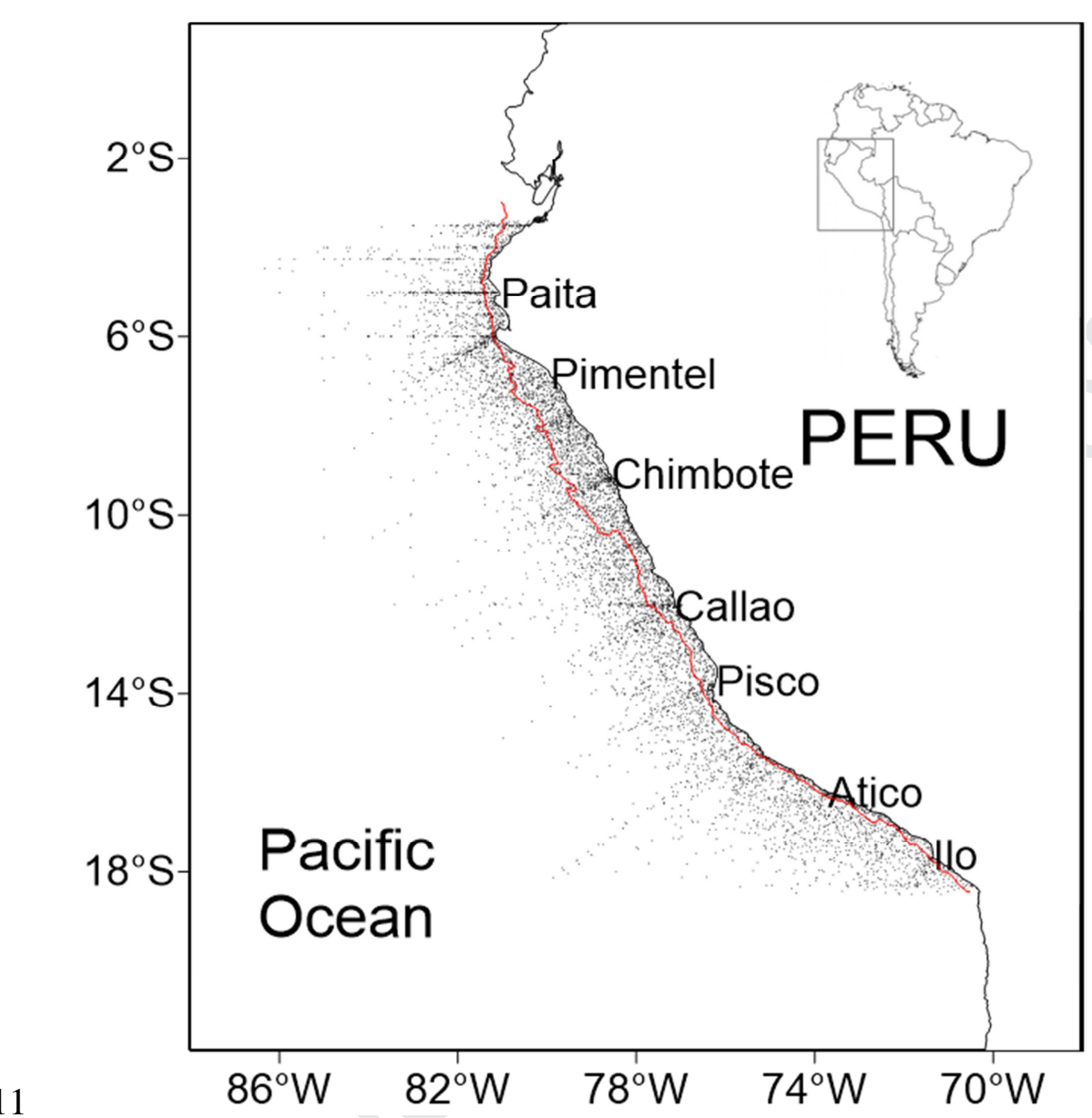

12 Fig. 1. Study area and position of the 7538 zooplankton sampling points (black dots). The

13 red solid line depicts the shelf break position (isobaths of $200 \mathrm{~m}$ ).

14

15 


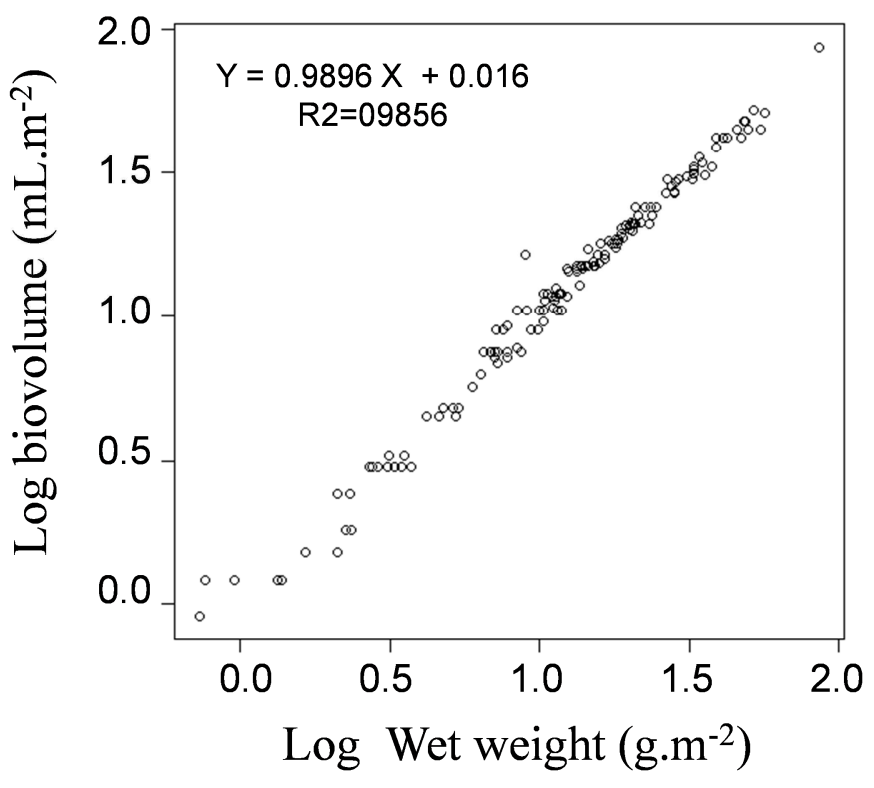

17 Fig. 2. Log-linear relationships between zooplankton biovolume and wet weight.

18

19 


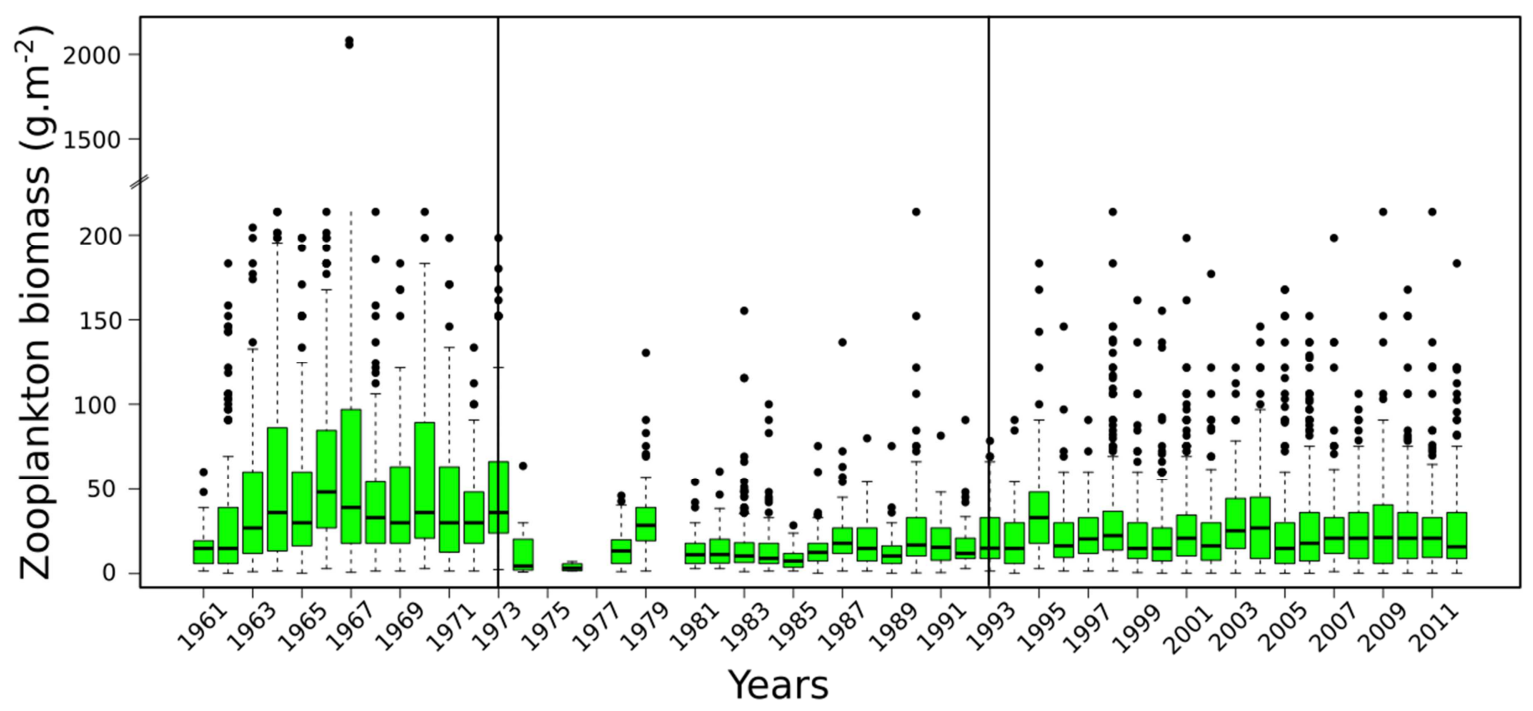

21 Fig. 3. Box plot of zooplankton biomass (in $\mathrm{g} \cdot \mathrm{m}^{-2}$ ) by year from $1961-2012$. The size of

22 the box is determined by the upper and lower quartiles, median is indicated as a horizontal

23 line inside the box. The black dots represent the outliers. The Chow test depicted two

24 significant shifts in 1973 and 1992 (vertical black lines). 


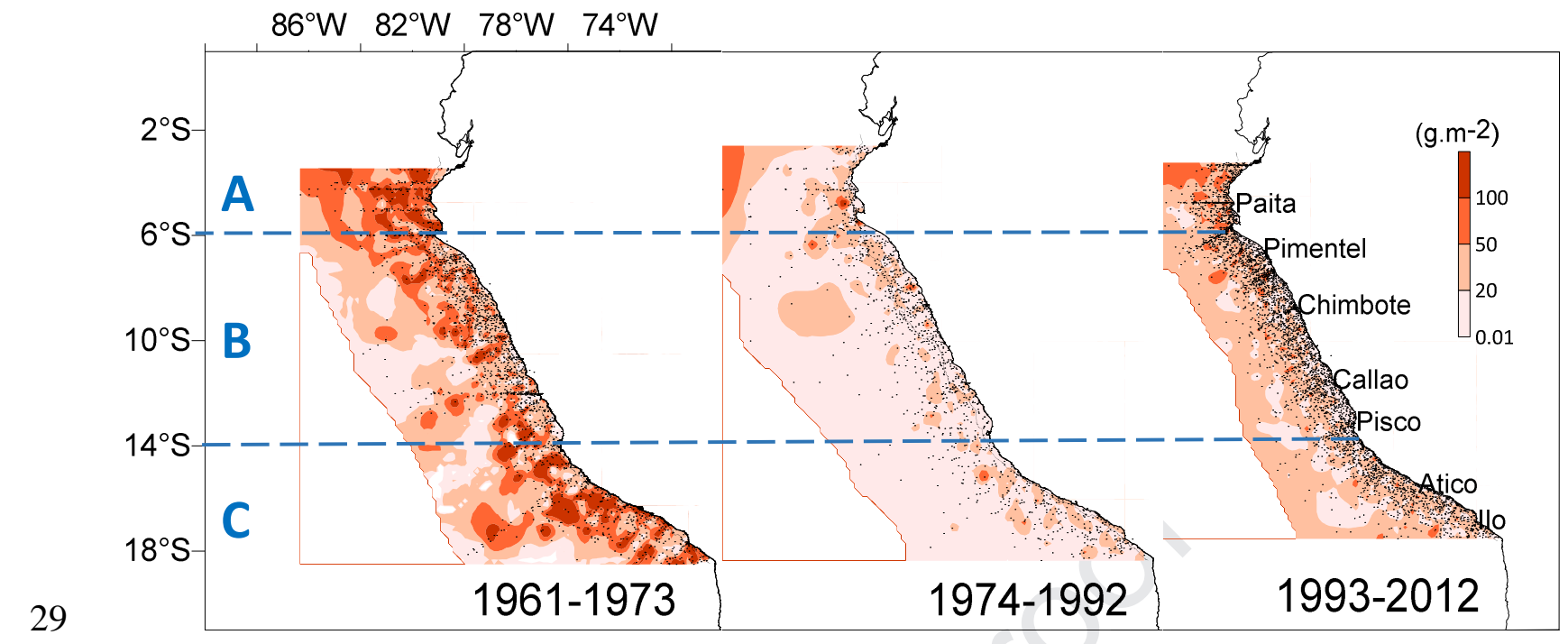

30 Fig. 4. Spatial distribution of zooplankton biomass (in $\mathrm{g} \mathrm{m}^{-2}$ ) by period. The horizontal

31 blue dashed lines depict the limit of the three latitudinal areas. The black dots represent the 32 sampling positions.

33 


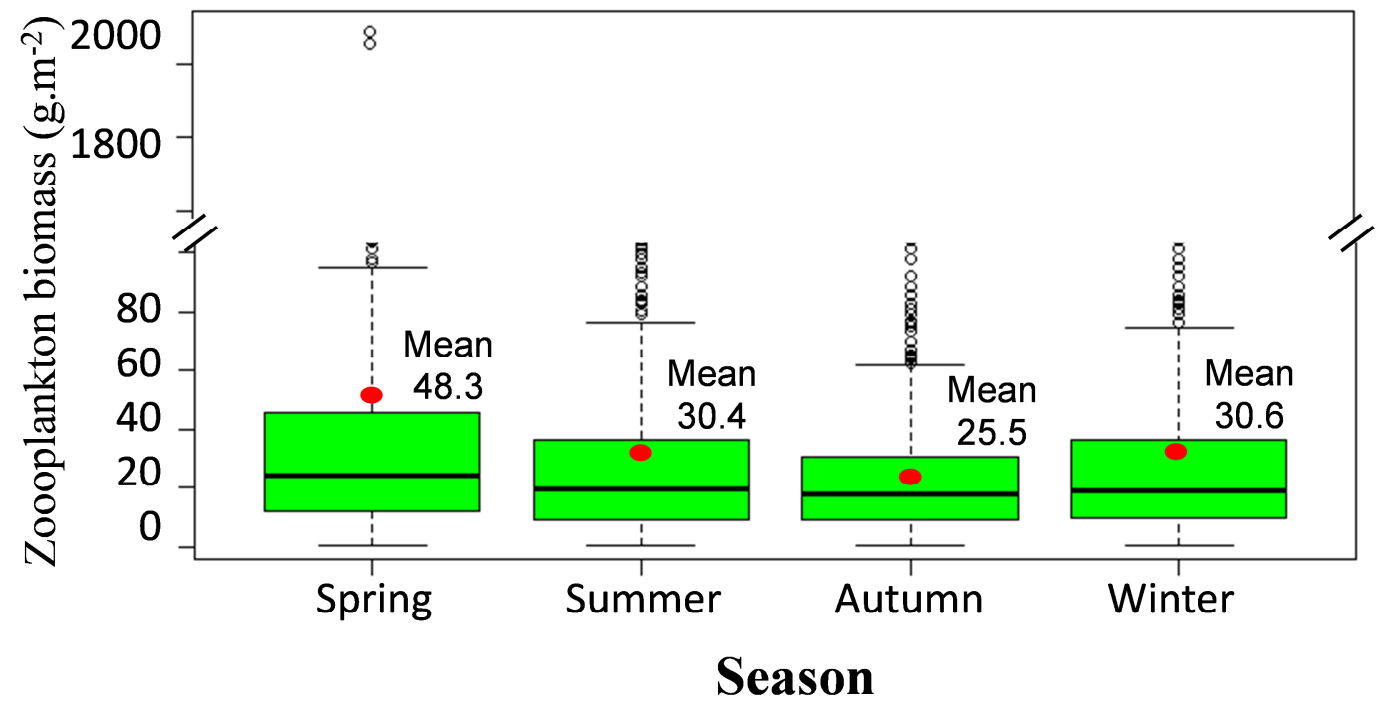

35

36 Fig. 5. Boxplot of zooplankton biomass (in $\mathrm{g} \mathrm{m}^{-2}$ ) by season. The black dots represent the 37 outliers.

38

39

40 


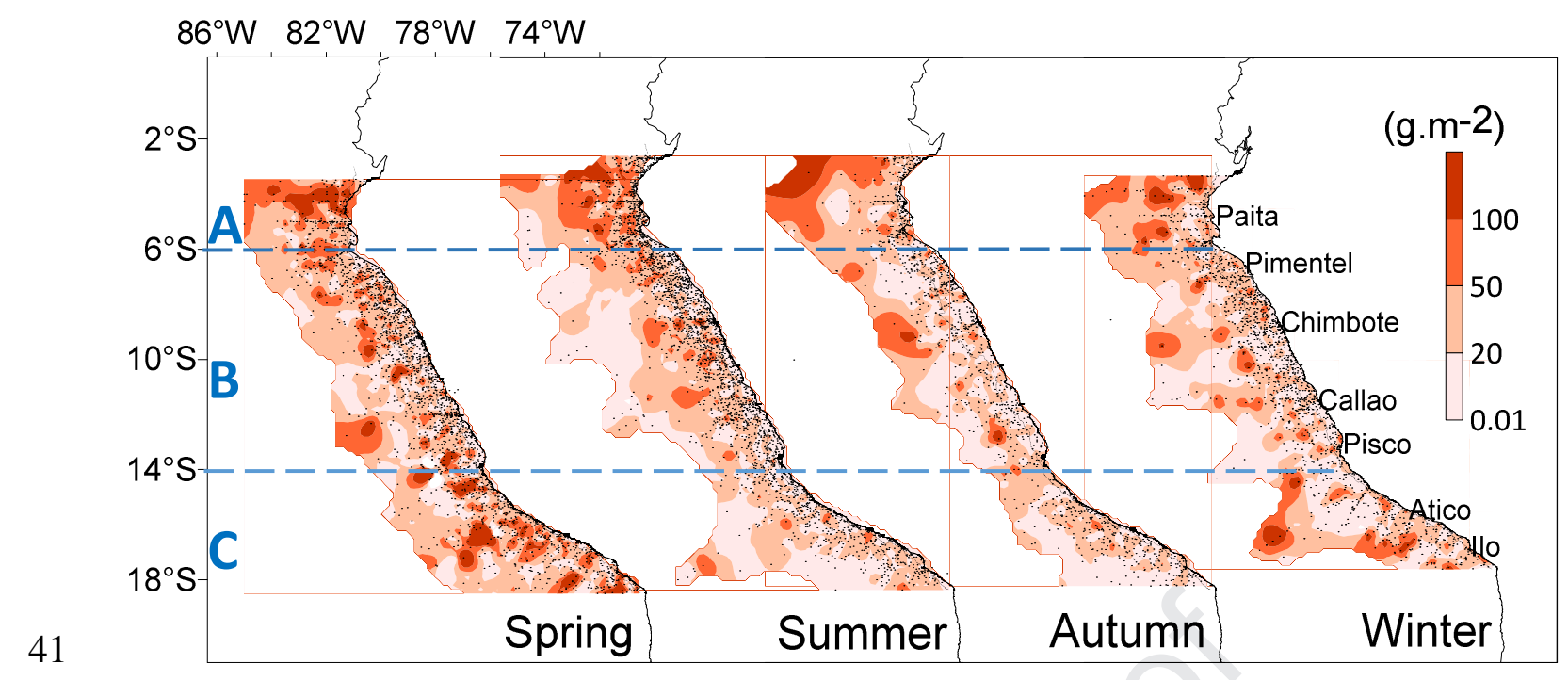

42 Fig. 6. Spatial distribution of zooplankton biomass (in $\mathrm{g} \mathrm{m}^{-2}$ ) by season. The horizontal

43 blue dashed lines depict the limit of the three latitudinal areas. The black dots represent the 44 sampling positions. 


\section{Katia Arones}

Instituto del Mar del Perú (IMARPE), Apartado 22, Callao, Perú

E-mail: karones72@gmail.com

Topic: Article DSR2_2018_176 R1 re-submission

Lima, September 30, 2019

Dear Editor

There are no conflicts of interest.

Katia Arones on the behalf of the authors (Daniel Grados, Patricia Ayón and Arnaud Bertrand). 